\title{
Diversity as a gift: LGBTQI+ Roman Catholic organizations in twenty-first-century Brazil
}

\author{
Cris Serra ${ }^{1}$ D
}

Received: 7 July 2021 / Accepted: 29 September 2021 /Published online: 9 November 2021

(c) The Author(s), under exclusive licence to Springer Nature Switzerland AG 2021

\begin{abstract}
This paper aims at examining the pluralization of Brazilian Catholicism with regard to the presence of sexual and gender diversity in Roman Catholic environments, in the context of the anti-gender attacks and growing use of Christian elements as political weapons in Latin American public debate since the 2010s. We set out to investigate the strategies used by Brazilian LGBTQI+ Roman Catholic groups to sustain their religious identity, beginning with a brief general comment on the ongoing Christian conversations on sexual and gender diversity, in an effort to go beyond the consolidated common sense of Christianity and sexual and gender diversity being irreconcilable. Next, we proceed to a brief overview of how Roman Catholic conversations on sexual and gender diversity have developed in Brazil in recent years. A short history of LGBTQI+ Roman Catholic communities in Brazil follows, highlighting their most relevant features. Finally, we move on to addressing such communities' theological production. What we seek to understand is how the organization of openly LGBTQI+ Roman Catholic communities results in the emergence of new theological and ecclesial subjects.
\end{abstract}

Keywords Sexual and gender diversity · LGBTQI+ · Brazilian Roman Catholicism · LGBTQI+ Roman Catholic groups

\section{Resumen}

Este artículo tiene como objetivo examinar la pluralización del catolicismo brasileño con respecto a la presencia de la diversidad sexual y de género en ambientes católicos romanos, en el contexto de los ataques anti-género y del uso creciente de elementos cristianos como armas políticas en el debate público latinoamericano desde los años 2010. Nos propusimos investigar las estrategias utilizadas por los grupos católicos romanos LGBTQI + brasileños para mantener su identidad religiosa, comenzando con un breve comentario general sobre las conversaciones cristianas en curso sobre

Cris Serra

cristiana.serra@gmail.com

1 Instituto de Medicina Social Hesio Cordeiro, Universidade do Estado do Rio de Janeiro, Rio de Janeiro, RJ, Brazil 
diversidad sexual y de género, en un esfuerzo por ir más allá del sentido común según el cual cristianismo y diversidad sexual y de género son irreconciliables. A continuación, procedemos a una breve descripción de cómo se han desarrollado las conversaciones católicas sobre la diversidad sexual y de género en Brasil en los últimos años. Luego se presenta una breve historia de las comunidades católicas romanas LGBTQI + en Brasil, destacando sus características más relevantes. Finalmente, pasamos a abordar la producción teológica de dichas comunidades. Lo que buscamos entender es cómo la organización de comunidades católicas romanas abiertamente LGBTQI + resulta en el surgimiento de nuevos sujetos teológicos y eclesiales.

Palabras clave Diversidad sexual y de género $\cdot$ LGBTQI+ $\cdot$ Catolicismo romano en Brasil · Grupos católicos LGBTQI+

\section{Resumo}

Este artigo tem como objetivo examinar a pluralização do catolicismo brasileiro no tocante à presença da diversidade sexual e de gênero em ambientes católicos romanos, no contexto dos ataques antigênero e do crescente uso de elementos cristãos como armas políticas no debate público latino-americano desde os anos 2010. Propusemo-nos a investigar as estratégias utilizadas por grupos católicos romanos LGBTQI+ no Brasil para manter sua identidade religiosa, começando com um breve comentário geral sobre os debates em curso nos cristianismos sobre diversidade sexual e de gênero, procurando ultrapassar o senso comum consolidado de que ambos são irreconciliáveis. A seguir, procedemos a uma visão geral de como vem se dando o diálogo entre catolicismo romano e diversidade sexual e de gênero no Brasil nos últimos anos. Segue-se uma breve história das comunidades católicas LGBTQI+ no Brasil, destacando suas características mais relevantes. Finalmente, abordamos sua produção teológica. O que buscamos entender é como a organização de comunidades católicas romanas abertamente LGBTQI+ resulta no surgimento de novos sujeitos teológicos e eclesiais.

Palavras-chave Diversidade sexual e de gênero $\cdot$ LGBTQI+ $\cdot$ Catolicismo romano no Brasil · Grupos católicos LGBTQI+

\section{Introduction}

A series of public controversies and political and electoral clashes throughout the 2010s helped consolidate, in Brazilian public imagination, the connection between "religion," especially Christianity, and "conservatism." Actors (self) identified as "Christians" and their allies, gathered under the conventional label of "Evangelicals," have actually been

\footnotetext{
${ }^{1}$ Labeling such variety of "Christian" actors and their allies "Evangelicals" stems from a widespread belief in a supposed homogeneity and cohesion of groups that mobilize around religious identities, especially Christian ones-ignoring differences between the various Protestant denominations and eclipsing the peculiarities of the intense engagement of Roman Catholic and Spiritist actors in Brazilian public debate.
} 
forging their political identity in Brazil in opposition to the ideals of human rights and the feminist and LGBTQI+ movements since the late 1980s, as described by Pierucci (1989; Vaggione 2020). These allegedly "religious" actors have been playing major roles in the broader anti-rights, anti-gender, and anti-pluralist moral crusade (Becker 1997 [1963]) that has taken Brazil (as most of Latin America) by storm since the 2010s. Such context has underpinned the preexisting common-sense notion that Christian religious belonging and sexual and gender diversity are irreconcilable.

There is nothing new to such perception, though. Indeed, building legitimacy and social space for sexual and gender diversity in modern Western societies has not been a linear process. Strained by contradictions and disputes, such process has challenged different social individual and collective actors into putting their own conceptions of sexuality and gender in question. That includes Christians and Christian communities-and not only at the institutional level. The responses built from dialog, conflicts, and tensions - both within Christianity and between Christianity and its "others"vary over time and correspond to a wide spectrum of attitudes. These range from repudiation and condemnation to exclusion of sexual and gender diversity, in accordance with a historically prevailing view, in the Christian West, of sex and the body as sources of danger, which restricts legitimate sexuality to reproduction. However, less evidently, Christian attitudes towards sexual and gender diversity also include the review and rectification of postures and doctrines on the subject, as well as a wide spectrum of welcoming initiatives and varying degrees of acceptance.

Nevertheless, there prevails the notion that "religion" (especially Christianity) and "sexuality" are antithetical fields-which emphasizes the supposedly repressive and standardizing role played by the former over the latter, mainly through religious institutions and authorities. In fact, the opposition between "sexuality" and "religion" as dichotomous and irreconcilable aspects of human life is a central and peculiar feature of the modern Western worldview. A representation of "religion" predominates in Western modernity, with special regard to Christianity, as an antiquated (when not retrograde, or even obscurantist) and prudish (or even repressive) domain. In contrast, "sexuality" would be concerned with the most expressive and authentic aspects of the "truth of oneself" (Duarte 2005). Nevertheless, both these two categories and the antagonism between them result from a historically situated cultural construction, as Asad (2011) reminds us.

Such dominant paradigm helps to cover up the ongoing conversations between Christianities and sexual and gender diversity, as well as the perviousness and malleability of the borders that constitute both domains - which then tend to be treated as if they were watertight and incommunicable vessels. Such conversations have been taking place in religious institutions and ecclesial environments in general amid the tension generated by the diffusion of modern ideas. They are also informed by a myriad forms of individual and collective resistance and dissidence by actors self-identified as Christian-thus contributing for the pluralization of the religious domain (Vaggione 2014) and, at the same time, blurring and expanding its boundaries.

In his preface to a Catholics for Choice publication in Argentina, Vaggione (2010) points out that both theoretical analyses and political practices often tend to ignore approaches to religion (especially Christianism) as a "progressive" force in 
terms of gender and sexuality. In fact, he says, one of the major challenges facing feminist movements and movements for sexual and gender diversity today consists in finding ways to incorporate a broader and more plural sense of religion. Based on "theoretical critical reflections on secularism as an ideology of modernity that essentializes (and somehow distorts) the complexity of religion in contemporary societies," Vaggione (2014, p. 222) objects to the common-sense notion that Roman Catholicism, especially in Latin America, is not negotiable. He advocates reinscribing religion "in plural terms within the (new) sexual politics," instead of expelling it (Vaggione 2014, p. 222).

Along the last decade, countries in Latin America and elsewhere have witnessed the increasing political use of Christian elements to buttress both the prevailing sexual and gender order and the social hierarchies built upon them. This has ultimately helped undermine the human rights discourse and even the democratic order itself, with its underlying pluralist logic (Corrêa 2020; Vaggione and Machado 2020; Brown 2006). Considering such context, this paper aims at examining the pluralization of Brazilian Catholicism with regard to the presence of sexual and gender diversity in Roman Catholic environments. Challenging the established common sense that Christianity and sexual and gender diversity are irreconcilable, we set out to investigate the strategies used by the Brazilian LGBTQI+ Roman Catholic groups, which started organizing in the late 2000s, to sustain their religious identity and stay in the Church. ${ }^{2}$ We hope our findings may contribute to avoid the automatic equivalence between religion and conservatism, joining the efforts to "re-appropriate religion in terms favorable to sexual freedom and diversity" (Vaggione 2014, p. 224).

This paper begins with a short comment on the ongoing Christian conversations on sexual and gender diversity; next, narrowing the focus to our specific subject, Roman Catholicism, we proceed to a brief overview of how Roman Catholic conversations on sexual and gender diversity have developed in Brazil in recent years. A summarized history of LGBTQI+ Roman Catholic communities in Brazil follows, highlighting their most relevant features. Finally, we move on to addressing their theological production.

Our research consisted in an ethnography of public online documents posted on the social networks of individual and collective actors linked to the Brazilian LGBTQI+ Roman Catholic movement, as well as observant participation in several in-person and virtual activities. What we sought to understand was how the organization of openly LGBTQI+ Roman Catholic communities results in the emergence of new theological and ecclesial subjects.

\footnotetext{
${ }^{2}$ By "Church," we refer to the broader set of Roman Catholic believers as "people of God," which includes ordained clergy and lay people, the high hierarchy, and the grassroots level. It is not restricted to the often used, strict sense of "hierarchy" or "institutional authority," unless where otherwise stated.
} 


\section{Conversations on sexual and gender diversity in Christian voices}

\section{Christianity and sexual and gender diversity}

The different ways in which Christianity, feminism, and sexual and gender diversity interact and influence each other in Latin America have been addressed by several authors (Vaggione 2008, 2010; Peñas and Sgró 2009). Bárcenas (2011), for instance, discusses how Mexican Christian churches and communities with a focus on LGBTQI+ people are spaces of resistance and search for legitimacy for sexual and gender diversity within Christianity. Jones and Vaggione (2012) emphasize the pluralism and complexity of religious (Christian) discourses in the public sphere concerning the legal recognition of same-sex couples in Argentina. In Brazil, Machado and Piccolo (2010) and their team interviewed religious (mostly Christian) leaders regarding homosexuality. Their research shows conflicts, tensions, and negotiations in both pastoral approaches and the concrete life of the faithful regarding the official doctrines of their religious institutions. Vaggione $(2005,2017)$ discusses the ongoing mirroring, by individual and collective Christian actors, of action and argumentation strategies developed by feminist and LGBTQI+ movements-such as the strategic use of grammars and categories originally developed in either legal and scientific fields, or human and civil rights activisms.

One of the effects of dichotomically opposing sexual and gender diversity and religion (especially Christianity) is a double invisibility. On the one hand, such opposition eclipses the presence of sexual and gender diversity in Christian faith communities. On the other, it hides the Christian faith and religious belonging of people outside the cis-heterosexual norm. ${ }^{3}$ Likewise, it erases the participation of Christian elements in the fight for LGBTQI+ rights and acceptance. That only makes all the more crucial to highlight initiatives like the one by Pacific School of Religion's Center for Lesbian and Gay Studies in Religion and Ministry, to create an online repository of profiles, oral history, and catalog data documenting the religious dimension of the history of the LGBTQI+ community, especially in the USA. ${ }^{4}$

Such alleged antagonism also contributes to spreading-and even justifyingforms of religious violence against people who dissent from the predominant sexual and gender norms. In fact, with regard to sexual and gender diversity, it is imperative to recognize and denounce the huge amount of violence that still prevails in society in general and how it reflects and translates into different Christian institutions and environments. It is also necessary to recognize that Christian tenets-or a Christianbased moral, even if explicitly Christian arguments are not used-are used to not only condemn sexual and gender diversity, but also justify and encourage forms of

\footnotetext{
3 The term "cisgender," as opposed to "transgender," refers to the experiences of identifying people, throughout their lives, with the sex/gender assigned to them and registered at birth. "Cis-heterosexuality" refers to the binary normative perspective, hegemonic in modern West, according to which a person can only be a man or a woman, in accordance with the gender assigned to them at birth, and can only establish relationships of love and desire with the opposite gender (Butler 2007).

4 The LGBTQ-RAN ("The lesbian, gay, bisexual, transgender and queer religious archives network") project is available at https://www.lgbtran.org/. Accessed 02 Jan 2021.
} 
physical and psychological violence against non-cis-heterosexual people. Violence includes, but is not limited to, doctrinal prescriptions of affective-sexual deprivation and the interdiction of gender expressions that depart from current norms and stereotypes, as well as more or less institutionalized rituals of "exorcism," prayers for "healing and liberation" and "reversal therapies," reaching extremes of aggression, torture, and even death.

Christian principles also undergird the violence of stigma (Goffman 1986 [1963]), which leads to shame, fear, guilt, silence, invisibility, and isolation. In the extreme, the ghosts of "sin" and impurity, as well as the fear of being an "abomination" in violation of "divine laws" (disguised or not as some form of transcendent "natural order") haunt the individual. Such ghosts follow even those who have already been expelled or self-exiled both from their community of origin (and often from friends and family) and from the sacred symbols and faith experience in which they were socialized, and which constitute significant religious references for them. Often, the individual (and those around them) is convinced that they carry something so evil that they believe to be unworthy not only of God's love, but even of any form of love bond. Believing that they are doomed to eternal damnation, in an attempt to be granted salvation, they often allow themselves to be subjected-or spontaneously submit themselves - to all kinds of flogging and mutilations of body and soul, even to the point of suicide (Gibbs and Goldbach 2015). ${ }^{5}$

Nevertheless, care must be taken so that the utmost importance of denouncing religious (Christian) violence against sexual and gender diversity does not result in reinforcing the dichotomy between the two domains. Ultimately, that would buttress both the political use of religious grammars against sexual and gender diversity and violence itself, which were to be fought in the first place (Vaggione 2014). Indeed, since neither the religious field nor ecclesial environments are monolithic or watertight, spaces for dialog, respect, and acceptance do emerge in heterogeneous faith communities and religious institutions. Christian condemnation not only of sexual and gender diversity, but of greater sexual and gender freedom in general as well, is certainly prevailing and much visible. Nevertheless, in real-life situations, varying degrees of integration of sexual and gender diversity to the ecclesial fabric are to be found. Actually, the typically modern "religion" vs. "sexuality" dichotomy translates into the very fact that such interrelationship remains mostly hidden both in the historiography of LGBTQI+ movements and in the recent history of Christianity and Christian Churches.

Indeed, despite the undisputable impact of doctrinal positions and ecclesiastical authorities' statements, these do not reflect the diversity of Christian stances regarding sexual morality in general and sexual and gender diversity in particular. Examining the Roman Catholic context shall help us better appreciate the complexity of

\footnotetext{
${ }^{5}$ Gibbs and Goldbach (2015) have found that LGBTQI+ young adults who mature in religious (Christian) contexts "have higher odds of suicidal thoughts, and more specifically chronic suicidal thoughts, as well as suicide attempt" compared to other LGBTQI+ young adults. In Brazil, the Federal and Regional Councils of Psychology, which are bodies that regulate the work of professional psychologists in the country, have published a book on the severely harmful effects of therapies that intend to allegedly "cure" LGBTQI+ people, generally based on Christian principles (Conselho Federal de Psicologia e Conselhos Regionais de Psicologia 2019).
} 
negotiations and disputes around the process of building legitimacy for sexual and gender diversity in Christian environments.

\section{Sexual and gender diversity in Roman Catholicism in the context of the anti-gender attacks in Latin America}

One of the major challenges currently facing sexual and gender diversity in Latin America is the growing mobilization of social actors against what they call "gender ideology." Such phrase was first coined and developed in Catholic environments, from the 1990s onwards, aiming at simultaneously delegitimizing gender studies, the LGBTQI+ and feminist movements and the struggles for the guarantee and expansion of sexual and reproductive rights (Vaggione 2020). Since then, it has also been adopted and disseminated by segments of other Christian churches-as well as by movements, groups, and actors that present themselves as Christians and/or make use of Christian vocabulary and rhetoric. In parts of Europe and across Latin America, "gender ideology" has become a crucial weapon in public debate, serving as "symbolic glue" to consolidate alliances that bring together different interests and groups around agendas against human rights and democratic logic (Serrano 2017). As such, the fight against "gender ideology" has been one of the defining characteristics of a phenomenon referred to by a growing number of authors as "new conservatism" or "neoconservatism" (Brown 2006; Vaggione 2020; Vaggione and Machado 2020), which relates to the rise of extreme right-wing populism in both continents.

The phrase "gender ideology" easily amalgamates elements that escape and/ or put in question the prevailing sexual and gender order. Such order essentializes and naturalizes whatever it means to be "man" and "woman" and converts the cisheterosexual binary into a supposedly universal and compulsory norm (Rubin 2012 [1984], Butler 2007). It also builds on a reified conception of "family"-one reduced to the arrangement comprised by a cis-heterosexual couple and their children, and organized according to a hierarchy that ranks men above women, and adults above youngsters. Whenever such strictly defined norms are not complied with, unequal, inferior treatment and marginalization, or even pathologization and/or criminalization, ensue.

Thus, "gender ideology" has been the ideal label to attach to whatever, or whoever, one chooses to define as aberrant, abject, or abominable-for instance, LGBTQI+ people or feminists, or their allies. Associating any individual or collective actor with "gender ideology" ultimately results in the kind of dehumanization described by Butler (2004) as justifying and endorsing their extermination, either symbolic or physical. Shaping up the ongoing "anti-gender" moral crusade as a new "witch hunt," and a Christian one for the most part, has proven to be a very effective rhetorical strategy.

A key element contributing to such effectiveness is the powerful political impact of certain uses of a religious grammar and esthetics in public debate. Indeed, the current anti-gender moral crusade is one much visible aspect of the 
growing introduction of Christian elements into Latin American public debate (and elsewhere) especially in the last decade, with two major consequences.

First, the introduction of religious elements into public, political debate reconfigures it as a moral one. Transposing the political debate to the terrain of morality makes it easier to reify categories that are actually conventional, such as family arrangements and gender roles-which allows them to be construed as having universal and transcendent value, making them impermeable to political analysis. Besides, reification narrows the margin of tolerance for both moral autonomy and discernment, on the one hand, and the coexistence of, and negotiation between, concomitant and divergent moralities, on the other. When social arrangements are thus reified and treated as absolute entities (Fassin 2011), any estrangement from the values that support them, any risk (even if only perceived) of interrupting their reproduction tend to be perceived as potential threats leading to the degeneration of the social fabric. The very survival of society appears to be at risk, unleashing intense social anxieties that easily trigger moral panics (Cohen 2011 [1972]) of the kind repeatedly seen across Latin America in recent years (Bárcenas 2018; Leite 2019).

Secondly, introducing a theological substrate into public debate allows specific images of "God" to be used, which in turn results in magnifying the above reification of conventional categories and arrangements. Most frequently, such "God" takes the form of an old white cis-heterosexual Man. "He" is an all-seeing, disembodied "eye" who is simultaneously everywhere and nowhere. Here is an exclusive and excluding "God," "whose Eye produces, appropriates, and orders all difference," in the words of Donna Haraway (1988, p. 587). Such old white cis-heterosexual male theocratic "God" is easily associated to a violent, belligerent, macho virility that overvalues aggressiveness to the detriment of empathy. Thus, shifting moral discourse into a theological one-and one with such specific features-not merely reinforces the reification of moral norms and imperatives by sacralizing them. Evoking such images of "God" results in sacralizing that specific sexual and gender hierarchy in which the white cis-heterosexual male indisputably holds the higher rank.

It was no accident that Roman Catholic actors first developed anti-gender discourses during the pontificate of John Paul II. In the Roman Catholic Church's relations with external actors and groups, Polish Pope Karol Wojtyla made history for his initiatives of interfaith dialog. In contrast, internally he left his conservative imprint, especially on moral issues - for which he counted upon the crucial collaboration of his Congregation for the Doctrine of the Faith (CDF) mayor and almost natural successor, German cardinal Joseph Ratzinger. Faced with the outbreak of the AIDS epidemic and the expansion of feminist and LGBTQI+ movements, Wojtyla responded by developing a "theology of the body" which sacralized the alleged "sexual difference" and supposed "complementarity" between men and women. Most importantly, it sacralized the sexual and gender hierarchy directly derived of such stated "difference"- the same hierarchy that is continuously challenged by the increasing legitimacy achieved by both feminist values and sexual and gender diversity. Wojtyla's "theology of the body" would be the cornerstone of the anti-gender moral crusade launched by Roman Catholic actors (clergy and lay people) in the 1990s (Girard 2008; Vaggione 2020). 
In 2005, Ratzinger became pope as Benedict XVI. News of his election was greeted with "dismay and concern [...] in some segments of society and the Church," Brazilian Jesuit Luis Corrêa Lima (2005) noted back then. One of the main causes of consternation was that Ratzinger, "labeled by some fierce critics as 'God's Rottweiler'," had, as mayor of the CDF, repeatedly condemned homosexual relations and same-sex marriage (Lima 2005).

According to another Brazilian Jesuit, liberation theologian João Batista Libânio (2009, p. 10), "By electing an elderly pope, one closely linked to John Paul II, the cardinals signaled their desire to continue the current theological and pastoral approach." Indeed, as Libânio stated back in 2009, in the Ratzinger era the emphasis on fidelity and commitment:

to both the doctrine of faith and to ecclesial practices emphasizing discipline and morals were maintained. [...] There is an ongoing effort to comply with the norms of liturgical, ecclesiastical and moral discipline, in addition to the rejection of all relativism. [...] Relativism continues to be the great adversary to be fought, for it corrodes the core of dogma. [...] Punishments of theologians continue, in the name of surveillance of sound doctrine. (Libânio 2009, p. 10)

It was during Wojtyla's pontificate, and under Ratzinger's supervision, that the Catechism of the Catholic Church, containing the Roman Catholic official doctrine, was produced and released. In its "Chastity and homosexuality" subsection, ${ }^{6}$ it acknowledges the existence of a "not negligible" number "of men and women who have deep-seated homosexual tendencies." It refers to "homosexual acts" as "intrinsically disordered," though, leading "homosexual persons" to be "called to chastity" (Catechism of the Catholic Church 1993, §2357-2359). In spite of its fleeting mention to "persons," the text focuses on justifying the interdiction of so-called acts, understood as practices to be avoided through "sacrifice." What the text makes clear is the refusal to see, listen to, and acknowledge not only the living realities of LGBTQI+ people, but also their legitimacy as interlocutors capable of bearing witness to their own experiences, speaking about themselves and for themselves. ${ }^{7}$ The resulting doctrine, based on theological abstractions disconnected from-and not interested inthe concrete lives of real people, has devastating consequences.

Nevertheless, the doctrine does not necessarily resonate in the daily lives and pastoral experiences of Roman Catholic clergy and lay people. For instance, several studies revealed varying discourses and attitudes of Roman Catholics towards the demands of feminist and LGBTQI+ movements (Machado and Piccolo 2010). According to Machado and Piccolo (2010, pp 50-51), such variation expressed

\footnotetext{
${ }^{6}$ Paragraphs 2357 to 2359 of the Catholic Catechism close a section entitled "The Vocation to Chastity." They follow the subsection on "Offenses against chastity"- - which include lust, masturbation, fornication, pornography, prostitution, and rape, in that order. The fact that the three-paragraph subsection on "Chastity and homosexuality" comes immediately after that list is suggestive of the status of homosexuality in the Catholic doctrine, as expressed in the Catechism.

7 Not surprisingly, as evidenced by the use of "homosexual" as an umbrella term, the Holy See consistently fails to update its vocabulary on sexual and gender diversity in the light of current scientific knowledge and, more importantly, of the terminology in use by the LGBTQI+ community itself.
} 
openness "to dialogue with other spheres of values in society" as well as to negotiate with "the discourse of human rights and with certain biomedical and psychological concepts."

In a paper also published in 2010, like Machado and Piccolo's book, Lima underscored how heterogeneous and "permeable to modern society" the ecclesial fabric was (Lima 2010, p. 423). He went on to point out how the Roman Catholic universe "encompasses multitudes of believers spread across the planet, a considerable cultural and ideological heterogeneity, and a wide diversity of ecclesial levels and environments" (Lima 2010, p. 424). In his discussion of counter-hegemonic stances towards sexual and gender diversity in Roman Catholicism, he enlisted several examples of pastoral initiatives, welcoming ministries, and statements by authorities, displaying a wide array of attitudes departing from the established doctrine. Even in the Ratzinger years, attitudes could differ considerably from official prescriptions and exhortations.

In stark contrast to his two immediate predecessors, from the beginning of Argentine Jesuit Jorge Bergoglio's pontificate, the image of a "LGBTQI+-friendly" pope has been building up-especially since his famous "who am I to judge?" question, made only a few months into his papacy, with wide repercussion in the global news. ${ }^{8}$ Although Bergoglio issues occasional statements either condemning "gender ideology" (to which he frequently refers as "ideological colonization") or restating the official doctrine towards homosexuality, he has also put a strong emphasis on pastoral care in general and engaged in an ongoing series of concrete welcoming gestures towards LGBTQI+ individuals and groups.

His conversation with Jesuits in Slovakia, in September 2021, illustrates the contradictions of him condemning "gender ideology" while focusing on a welcoming pastoral approach towards sexual and gender diversity. Asked about the dangers of "ideological colonization," he said:

The "gender" ideology of which you speak is dangerous, yes. As I understand it, it is so because it is abstract with respect to the concrete life of a person, as if a person could decide abstractly at will if and when to be a man or a woman. Abstraction is always a problem for me. This has nothing to do with the homosexual issue, though. If there is a homosexual couple, we can do pastoral work with them, move forward in our encounter with Christ. When I talk about ideology, I'm talking about the idea, the abstraction in which everything is possible, not about the concrete life of people and their real situation. (in Shine 2021)

Commenting on Bergoglio's interview in Slovakia, Robert Shine, from American LGBTQI+ Catholic organization New Ways Ministry, summarizes current Roman Catholic tensions around sexual and gender diversity:

\footnotetext{
${ }^{8}$ As it happens, on that occasion Bergoglio was be the first pope ever to pronounce the word "gay" (referring to a "gay person") in a public statement.
} 
[By] affirming the need for pastoral care while criticizing so-called "gender ideology" $[\ldots]$ the pope perpetuates his mixed record. For many Catholics, Francis is making unprecedented strides to a more welcoming church. For some, condemnatory teachings undercut any positive statements. For others, the ambiguity inherent to the pope's approach just leaves them confused. And for conservatives, the mere suggestion of better pastoral care is anathema. (Shine 2021)

Bergoglio's emphasis on pastoral action and "the concrete life of people" combine to his welcoming gestures towards LGBTQI+ Catholics, undeniably affecting the varying attitudes towards sexual and gender diversity in Roman Catholic environments. For all its limitations, his stance stands in sharp contrast with both moralism and the emphasis on doctrinal, normative, and abstract theologies that prevailed in the two previous pontificates - and still do in far from negligible sectors of the Catholic Church. In addition, a series of statements and documents, among which apostolic exhortations Evangelii Gaudium (2013) and Amoris Laetitia (2016) stand out, have been remodeling moral and ecclesiological paradigms (Lima 2021), shaking consolidated structures, and radically straining the ecclesial fabric. Not surprisingly, among Bergoglio's fiercest opponents are so-called "ultra-Catholics" and other farright actors and groups, who figure among the most committed anti-gender moral crusaders.

Bergoglio's pontificate evidences the paradoxes of the Roman Catholic Church as a complex, heterogeneous network of relationships and discourses, one that is permeable to multiple influences and finds itself in constant interaction with several other social environments and actors.

As a case in point, one cannot overemphasize that all documents on gender and sexuality issues the Curia has released are responses and reactions to debates and developments taking place also within Roman Catholic borders; as such, they are part of an ongoing dialog. The list ranges from the encyclical Humanae Vitae (1968), through the declaration Persona Humana (1975) and the letter Homossexualitatis Problema (1986), to the recent document by the Congregation for Catholic Education, Male and Female He Created Them (2019). It is characteristic of the normative purpose of such doctrinal documents that they are treated as the legitimate and exclusive expression of a supposedly unequivocal and unified position of "The Church." ${ }^{9}$ Notwithstanding, quite the contrary is true: not only such documents fall within a broader flow of negotiations and contradictions, but they are far from representing a definitive resolution for them.

In Brazil, according to Lima (2021), in the last decade, there has been growing demand and interest on the part of both clergy and lay Catholics for information, resources and guidance for carrying out pastoral ministry to LGBTQI+ people. Such tendency has clearly intensified since the beginning of Bergoglio's pontificate. On the other hand, it remains a challenge for both lay leaders in ecclesial environments

\footnotetext{
${ }^{9}$ It is a powerful rhetorical and political artifice that "The Church" is presented as a monolithic and homogeneous body in which the institutional authority and the "people of God" in its entirety are conveniently and inextricably blended.
} 
and clergy people, especially at the grassroots levels, to undertake pastoral work aimed at LGBTQI+ people-and even more so to openly raise objections to the official doctrine on sexual and gender diversity. They risk suffering negative reactions and pressures from individuals or groups, as well as sanctions from their superiors. Once again, the paradoxes straining the Roman Catholic ecclesial fabric are evident.

In addition, since the COVID pandemic broke out, a tendency has consolidated for masses, homilies, and commentary in different contexts to be made available online. In Brazil, this has led to a growing number of clerics suffering vicious attacks for expressing welcoming and tolerant stances towards sexual and gender diversity. It would seem that the escalation of disputes around moral values and the use of Christian elements in public debate, in the context of the ongoing anti-gender crusade, have partially resulted in renewed silencing of the debates on sexual and gender diversity in Roman Catholic environments in Brazil.

\section{The Brazilian LGBTQI+ Roman Catholic movement}

\section{Historical context: Brief overview of LTBTQI+ Christian movements}

In such a highly complex, heterogeneous, contradictory ecclesial context concerning moral and sexual doctrine, and especially with regard to sexual and gender diversity, the first Brazilian group aiming at reconciling what they called a "dual identity"that is, identifying as LGBTQI+ without giving up their Roman Catholic faith and belonging - arose in Rio de Janeiro in 2007. As to Spanish-speaking Latin America, Padis+ Chile was born as a "Sexual Diversity Pastoral Council" in Santiago towards the end of 2010, under the wing of a local Christian Life Community (CLC/CVX) and accompanied by Jesuit Pedro Labrín.

Outside Latin America, however, the first initiatives for creating safe, affirming spaces to Christians who do not identify with cis-heterosexuality date back to the late 1960s, when they arose in the wake of the political strengthening and escalation of (then-called) gay rights activism. For instance, the Metropolitan Community Churches (MCC), founded in Los Angeles in 1968 by gay Baptist preacher Troy Perry, became the first Christian denomination explicitly dedicated to sexual and gender diversity, giving rise to the inclusive churches tradition. Such is a heterogeneous arena, marked by the variety of theological-pastoral approaches, providing crucially important welcoming, affirming spaces for sexual and gender diversity in Christian context (Freire 2019; Musskopf 2021).

Pioneering Roman Catholic group Dignity, now DignityUSA, was born in California in early 1969, months before the Stonewall Uprising - the six-day riot against police abuse in a New York gay club celebrated as a major founding landmark of the now-called LGBTQI+ movement. Back in those days, same-sex sexual intercourse was still a crime in all US states but one; medical and psychological professional associations classified homosexuality as a mental disorder; and the then-called gay community barely took its first steps towards organizing to fight for its rights. It was in such context that Augustinian priest and psychologist Patrick Nidorf took the initiative to start a ministry for gay and lesbian Catholics, raising immediate, 
significant interest among them (DignityUSA n.d.), and demonstrating the perviousness of the boundaries across which Roman Catholicism and sexual and gender diversity communicate.

From then on, there emerged in the USA various initiatives aiming at embracing sexual and gender diversity within different Christian denominations. In the wake of Dignity, throughout the 1970s, several other movements were organized, such as Integrity (Anglican Episcopalians, 1974), Lutherans Concerned (Lutherans, 1974), and Affirmation (United Methodists, 1975), to name a few. In Australia, Acceptance had been created in Sydney in 1972.

Since then, similar collectives, coalitions, and ecumenical networks around the world have emerged and consolidated. In Europe, the European Forum of Lesbian, Gay, Bisexual, and Transgender Christian Groups is an ecumenical network comprising over forty LGBTQI+ Christian communities from over twenty countries. Émile Letertre, a Roman Catholic priest who was a member of French LGBTQI+ Catholic group David et Jonathan, invited groups from across the continent to a first meeting in Paris, in 1982; the Forum was born on that occasion (Quentin 2015).

In October 2015, the Global Network of Rainbow Catholics (GNRC) held its inaugural assembly in Rome, entitled "LGBT Voices to the Synod." Organized by a coalition of Roman Catholic LGBTQI+ groups, the assembly brought together representatives from over thirty countries (DeBernardo 2015) in time to address an open letter to the delegates at the Synod of the Bishops on the Family, held at the Vatican that same month. The letter read:

Many in our Church thought that they were serving God by hating us, and some still do, especially among the hierarchy; but we can tell you with joy, that we have kept alive our Confession of the Catholic faith! We have kept the faith under persecution [...]. We have learned that it is not what the Church can do for us, but what we can do for the Church that matters. [...] We have prayed for you at every Mass at our meeting, and we ask you to pray for us, confident that we will soon be able to meet transparently, with joy. (GNRC 2015)

Up to September 2021, the GNRC gathered 46 member communities from all over the world-four of them in North America (USA and Canada), eight in Africa, seven in the Asia-Pacific region, eight in Latin America, and nineteen in Europe.

Most of such organizations provide guidance and support to non-cis-heterosexual Christians, fostering an affirmative stance and fighting for their rights and equality. In contrast to inclusive churches, which constitute separate denominations, these collectives and movements demand space and recognition within their original Churches, where they strive to stay. By fostering the full inclusion of the LGBTQI+ faithful in their respective denominations, they create spaces of dissidence and resistance, especially in those Christian communities and institutions in which moral rigor and defense of a restrictive sexual and gender order prevail (Vaggione 2014).

A relevant contributing factor for LGBTQI+ Roman Catholic groups having only appeared in Latin America in the 2000s lies in the peculiarities of Latin American sexual and gender diversity movements. In the USA and Europe, the emerging gay liberation movement flourished in the 1970s in the wake of the so-called sexual revolution and the civil rights turmoil of the 1960s. In Latin America, in contrast, 
conservative, right-wing governments - which in several cases degenerated into violent dictatorships - prevailed in most of the region between the 1970s and the 1980s, to which the outbreak of the AIDS epidemic followed. Combined with cultural singularities of each country, that led sexual and gender diversity movements to organize at very different paces and with distinguishing features in each case (Encarnación 2016; Simões and Facchini 2009).

On the other hand, it might seem reasonable to expect that the Liberation Theology framework would have provided theoretical-methodological subsidies for the elaboration of Latin American Christian theologies that would not address sexual and gender diversity in terms of incompatibility and antagonism. Nevertheless, as Brazilian Lutheran theologian André Musskopf points out, "Liberation Theology could not (or would not) grapple with gender- and sexuality-related issues" (Musskopf 2008, p. 162). He suggests that such void may be due to the "sexism" and "heterosexism" of the founders of Liberation Theology, on the one hand, and, on the other, of the Latin American left itself, with its emphasis on class analysis and prevailing contempt for identity-and especially gender and sexuality-issues and agendas. It was only from the 1980s and 1990s on that a number of sophisticated Latin American theologies on sexual and gender diversity first emerged, among which that of Argentine theologian Marcella Althaus-Reid stands out (Althaus-Reid 1994, 1997, 2000). That was not the case of Roman Catholicism though, in which Wojtyla's forceful conservative backlash was taking place.

Additionally, in the Latin American political-religious context, one cannot ignore the political weight of Christian individual and collective actors in the public debate. Besides the role the Roman Catholic Church institution has historically played as a major political force throughout the region since colonial times, since the late 1980s, so-called Evangelicals, especially in Brazil, have acquired increasing relevance in the public sphere. It cannot be stressed enough that one of the major features of the public/political collective identity such Christian actors ${ }^{10}$ have forged for themselves is their opposition to both feminisms and sexual and gender diversity, as noted above (Vaggione and Machado 2020; Vaggione 2020).

Such are some of the regional peculiarities that have certainly affected both the attainment of public legitimacy for sexual and gender diversity, on the one hand, and, on the other, how non-cis-heterosexual political identities consolidated in Latin America in the last decades of the twentieth century, as compared to the Global North. Notwithstanding, the first Latin American inclusive churches emerged in the 1980s and 1990s (Musskopf 2008, 2021), revealing not only a demand by non-cisheterosexual Christians for safe spaces where to openly live and share their faith, but actually their own initiative to create such spaces. The fact that they were not willing to give up neither their Christian faith nor their dissident sexual and gender experiences hints not only at the consolidation of non-cis-heterosexual identities, but also at the tensions and negotiations involved in the attempt to reconcile those with

\footnotetext{
${ }_{10}$ As already stated, individual and collective religious actors subsumed under the label "Evangelicals," especially in the Brazilian context, are actually much diverse in their characteristics and action strategies and include conservative and ultraconservative Roman Catholics.
} 
Christian identities and belonging. Above all, it indicates the impending emergence of new ecclesial subjects within Latin American Christianity.

\section{"Pre-history" of the LTBTQI+ Roman Catholic movement in Brazil}

To understand the emergence of LGBTQI+ Roman Catholic groups in Brazil in the late 2000s, one cannot ignore neither the above seen context of the broader LGBTQI+ Catholic movements in the world nor the existing debate on sexual and gender diversity in Roman Catholicism in Brazil, however modest, in the final decades of the twentieth century. Such debate can be glimpsed at through the scarce Roman Catholic literature on sexual and gender diversity published in Brazil at the time, as well as through clues on LGBTQI+-related pastoral initiatives by Brazilian Catholic priests.

In a 1979 paper, Irish Redemptorist Raphael Gallagher described the treatment given to homosexuality in Roman Catholic "traditional" moral theology (i.e., that of moral "manuals") as "usually short, precise, and confidently presented as the only possible one, given the unanimity of the biblical data, theological tradition and the attitudes of the believing community" (Gallagher 1979, p. 555). Nevertheless, in the early 2000s, there was in Brazilian bookstores some literature in Portuguese to be found that did not address sexual and gender diversity and the Roman Catholic faith in necessarily irreconcilable terms.

Such literature reveals Roman Catholicism's perviousness to the matter, as part of an ongoing conversation with LGBTQI+ real lives. Gallagher himself began his paper by describing the pressures suffered by moral theologians to reconsider the traditional Roman Catholic treatment given to the issue of homosexuality. Among those, he included "the ongoing revision of the methodology of moral theology itself, new exegetical interpretations of the relevant biblical data and increasing evidence from the scientific community on the causes and development of homosexual orientation and actions in particular persons." Such pressures, he noted, "have become public and have been harnessed by politically conscious homosexuals" (Gallagher 1979, p. 555).

As early as 1967, Brazilian Vozes Magazine, published by Franciscan press Editora Vozes and described as "a Catholic cultural magazine" (Green 1999, p. 193), had issued an article on homosexuality whose title roughly translated as "They are also of our lineage: considerations on homophilia" (Snoek 1967). Its author was Jaime Snoek, a Dutch Redemptorist living in Brazil. In consonance with the Dutch Pastoral Institute guidelines, he understood homosexuality was not a disease. On the contrary, he posited, whatever "symptoms" were allegedly related to homosexuality "should be exclusively attributed to exogenous factors, especially sociological ones: the fact of being different from others, in a minority and isolated group; boredom of life, guilt, dread of eternal damnation, etc.” (Snoek 1967, p. 795). However pioneering his article was, though, Snoek would remain as an "isolated voice of toleration," in the words of Green (1999, p. 193).

Only ten years later, in 1977, would a major Brazilian publishing company-yet a non-Catholic one-release a book by a Roman Catholic priest on the subject, whose 
French original dated from two years earlier (Oraison 1977). Its author was Marc Oraison, who was then famous for challenging the positions of the Roman Catholic Church hierarchy towards different themes in the field of sexuality-his book Christian Life and Problems of Sexuality had been included in the Index of Forbidden Books (National Catholic Reporter 1966).

In 1982, Editora Vozes was the first Roman Catholic press in Brazil to release a book on Catholic sexual morality. The original, Human sexuality: new directions in American Catholic thought (Kosnik et al. 1977, 1982), had been commissioned in 1972 by the Catholic Theological Society of America to a committee headed by Roman Catholic priest and professor of moral theology Anthony Kosnik. Directed to theologians, pastoral agents, and interested lay people, the book aimed at arriving at "helpful and illuminating guidelines in the present confusion" concerning "the adequacy of traditional Catholic formulations and pastoral responses to sexual matters" (in Frayser and Whitby 1995, p. 509). A few months after its publication in the USA, the American Episcopal Conference issued a statement condemning the book. Two years later, a letter from the CDF backing the American bishops' decision mentioned the widespread publicity the work had garnered and its various translations into other languages (CDF 1979). Bearing witness to the book's impact is the fact that the Brazilian publishing house decided to release it despite its condemnation by the CDF five years earlier.

In 1985, Jesuit-run Edições Loyola released Homosexuality: science and conscience (Vidal et al. 1998 [1985]), a translation of a 1981 Spanish book. The foreword justifies its publication as follows: "public and organized manifestations of homosexuals in recent years pose a new question to our society and each one of us. [...] the fact leaves us stunned [...]: 'they are many, and apparently equal to us!'” (Vidal et al. 1998, p. 5). The book aimed at promoting a conversation among specialists from several different fields in order to clarify, "beyond fear, the possibilities of coexistence and the - also religious - roots of the strong environmental condemnation" of homosexuality (Vidal et al. 1998, p. 6). The foreword ended up by stating: "This is an effort of interdisciplinary scientific consideration [...] born from the clinical and pastoral coexistence/experience" (Vidal et al. 1998, p. 6). ${ }^{11}$

In 1988, a Jesuit theology journal published an article entitled "Homosexuals and ethics of liberation," by Bernardino Leers. A Dutch Franciscan living in Brazil, Leers was a moral theologian, keen on the Second Vatican Council's proposals to open the Roman Catholic Church to a conversation with modern ideas. His text began by attributing the difficulty of "addressing the moral problem of homosexuality" to "discrimination"- - which was "intimately linked to the dominant religious convictions" (Leers 1988, p. 294). According to him:

\footnotetext{
11 The main author of the book, Spanish Redemptorist Marciano Vidal, would receive a public notification from the CDF in 2001, pointing out "the ambiguities and errors contained in widely-distributed works" (CDF 2001). In 2012, the CDF would forbid an Argentine publisher to release one of its books, this one specifically on homosexuality - even though they did not object to its Brazilian, Chilean, or Spanish versions (Vidal 2012). Redemptorist publishing house Santuário had published it in Brazil in 2008 (Vidal 2008).
} 
These are times when cultural sensitivity places freedom at the center of attention and of struggles, times when new forms of slavery and death are constantly found out. It is understandable that not only homosexuals begin to openly revolt against the prison in which society keeps them, but also that ethics itself feels obliged to interrogate the very tradition of norms and reasons that, if perhaps has not built such prison, has at least legitimized its existence. (Leers 1988, p. 294)

In 1990, Redemptorist press Editora Santuário published the aforementioned paper by Raphael Gallagher (1979, 1990), Understanding the Homosexual. While it had been released as a booklet in Dublin in 1985, its original publication dated back to 1979 , when it appeared in the Irish theological magazine The Furrow-self-presented as a "courageous and impartial forum for discussion of challenges facing the Church today and of the resources available to meet them" (The Furrow n.d.). Gallagher stated his intention to approach the subject based both on existing literature and "perhaps more importantly, what I have learned from homosexuals themselves and from those who have been working with homosexuals" (Gallagher 1979, p. $555)$.

In 1998, another non-Catholic publisher, through a label that targeted the LGBTQI+ audience, released What the Bible Really Says about Homosexuality by Daniel Helminiak. ${ }^{12}$ In order to legitimate the author, it stressed that he was a Roman Catholic priest (Helminiak 1998, p. 133)—while omitting that he had come out gay in the mid-1970s (Helminiak 2016). Helminiak did acknowledge, though, that since 1977 he had ministered to the lesbian and gay community, mostly through Dignity (Helminiak 1998, p. 13).

It had taken Helminiak three years to find a publisher willing to release his book. In his own words: "The religious publishers said it was too one-sided. They meant it was on the wrong side. The gay publishers said it would not sell" (Helminiak 2016). The book turned out to be a best seller though; by 2016, it had sold more than 100,000 copies and translated into seven languages. In his preface to the first edition, Helminiak explained his purpose in writing it: "Bible religion plays a major role in allowing violence against lesbian and gay people to occur. Quote the Bible, and all discussion suddenly comes to an end. Supposedly, the Bible condemns homosexuality, and some people take that to mean that the Bible justifies hatred and cruelty against gays and lesbians" (Helminiak 1998, pp. 14-15). ${ }^{13}$

Also in 1998, Editora Vozes released the first publication on a welcoming pastoral experience with sexual and gender diversity within Roman Catholicism in Brazil. In his book, Pastoral Care for Homosexuals (Trasferetti 1998), Roman Catholic priest José Trasferetti recounted his own experience at the head of a parish on the outskirts

\footnotetext{
12 Helminiak's book had originally appeared in 1994; a new, updated, and expanded version would come out in the USA in 2000.

13 The Roman Catholic Church hierarchy, he claims, has not sanctioned him. He says he sent a copy of the book to his bishop at the time, "as was my custom in publishing anything when I was still in the priesthood," but "unlike in earlier cases, I never received a letter of acknowledgement from my bishop" (Helminiak 2016). The following year, Helminiak resigned from priesthood.
} 
of Campinas, in the state of São Paulo, since 1994. His contact with the dwellers of a house in his parish—some of whom, he said, were homosexuals, whereas other were transvestites-had led him to the conclusion that they were "normal [people] like all of us, only different in their sexual orientation" (Trasferetti 1998). "In addition to welcoming them," he would recall in an interview in 2008, "I morally prepared the community for getting to know their reality. [...] I also welcomed [...] their parents, brothers and friends" (Trasferetti 2008, p. 13).

A journalist had coined the phrase "pastoral care for homosexuals" in his story on Trasferetti's activities for a local newspaper (Trasferetti 1998). In a later interview in 1995 for a national newspaper (which similarly referred to "pastoral care for gays"), Trasferetti had had to explain, "There is no institutional initiative in the church targeting such audience," although he himself felt "that there is a huge demand" (Trasferetti 1995). He had took the opportunity to explain his vision. It was about:

an accompaniment and pastoral care service, targeted at people from the periphery, the poor, young people who do not find acceptance in school, in the family, in society, in the church. [...] People who, when faced with homosexuality, are excluded, are kept on the sidelines, because they cannot find a job, because their family excludes them [...] and they feel rejected and exclude themselves. [...] These human beings need to be loved and respected. This has biblical reasons. [...] We must also provide them with the opportunity of gathering to meet each other. [...] It is equally necessary to raise people's awareness to the matter, giving no margin for a priori discrimination. (Trasferetti $1995)^{14}$

Although Trasferetti was removed to another parish in 2000, since then reducing his pastoral ministry (Trasferetti 2008, p. 13), he kept engaged with the issue of sexual and gender diversity as a moral theologian. In 2002, for instance, he co-authored Homosexuals and Christian Ethics with Bernardino Leers, combining his own pastoral experience to Leers' considerations on moral theology (Trasferetti and Leers 2002). ${ }^{15}$ In his foreword to the book, Franciscan Luiz Augusto de Mattos stated:

The current sociocultural scenario leads us to believe that one cannot ignore the new and growing visibility of the homosexual cause. [...] It is unfair and irresponsible to keep on discriminating, excluding and disregarding people who are structurally homosexual (or have such affective-sexual tendency) because of sexism, patriarchy, heterosexualism, homophobia (Mattos 2002, p. 10).

\footnotetext{
${ }^{14}$ Shortly after that interview, a respected Brazilian gay rights activist organization granted Trasferetti their "Pink Triangle Trophy," annually awarded to individuals and institutions that stand out "in supporting the human rights of homosexuals" (Mott 2006, p. 17).

${ }^{15}$ Leers, in turn, would gather part of his own reflections on the subject in a paper entitled "Homosexuals and Christian Ethics," which came out in the Brazilian Conference of Religious Workers' Convergência magazine that same year (Leers 2002).
} 
Meanwhile, in 2001, Editora Vozes had released The enigma of the sphinx: sexuality, by Franciscan Antonio Moser (2001)—who, according to Musskopf (2008, p. 201), strived to disentangle homosexuality from the broader discussion of sexuality to focus on a pastoral approach instead.

In 2005, Edições Loyola published the translation of Sexual Diversity and Catholicism: Towards the Development of Moral Theology (Jung and Coray 2015). The book had originally come out in the USA four years earlier, as the result of a symposium held in 1999 at the Loyola University Chicago, seeking to undertake a critical analysis of Roman Catholic moral doctrine on "homosexuality."

Little before then, in 2004, Jesuit Luís Corrêa Lima had begun teaching at Jesuitrun Pontifical Catholic University of Rio de Janeiro. Upon entering the Jesuit novitiate, in 1985, Lima had worked with Trasferetti in Campinas. By reading Trasferetti and Leers' book in 2003, he had found theological elements to support what he would later describe as his "intellectual conversion to inclusive Christianity."16

Ten days after Ratzinger's election as pope, in 2005, a brief commentary by Lima on the status of sexual and gender diversity in Roman Catholicism appeared in the Opinion section of one of the largest Brazilian national newspapers. He acknowledged criticisms that the Roman Catholic Church undermined LGBTQI+ people's self-esteem, "inflicting enormous psychological suffering on millions of them, in addition to stimulating social hatred against homosexuals." However, he stressed, "The Church's posture is rich and complex [...]. Some of such positions, if decontextualized and repeated with insistence, favor intolerance - while others favor tolerance and constructive conversations" (Lima 2005).

The following year, Lima would start a research group on "sexual diversity, citizenship and religion" at the university, in order to approach "homosexuality, transsexuality and their complex relationships with religion, especially Christianity [...]. It seeks to raise existing conflicts and possibilities of convergence, as well as to elaborate considerations and subsidies for new forms of coexistence and interaction" (Grupo de Pesquisa Diversidade Sexual, Cidadania e Religião 2017).

That first newspaper article was the starting point of Lima's prolific activity, which continues to this day and has turned him into an inescapable voice in the Roman Catholic conversation on sexual and gender diversity in Brazil. Thanks to his insightful writings and extensive experience in pastoral ministry with LGBTQI+ Catholics, as a crucial ally of the Brazilian LGBTQI+ Catholic communities, clergy and lay Catholics alike look to him as a source of support and pastoral subsidies. ${ }^{17}$

Mapping those Brazilian publications from the late 1960s to the early 2000s that did not take the incompatibility between sexual and gender diversity and Roman Catholic faith for granted allows a glimpse of how provoked Roman Catholics were by the burgeoning public visibility and gradually acquired legitimacy of sexual and gender diversity. Indeed, references to a state of "confusion" (Kosnik et al. 1977)

\footnotetext{
16 Personal communication

17 In 2021, Editora Vozes published Lima's first book, Theology and the LGBT+: Historical Perspective and Contemporary Challenges (Lima 2021). His research group's blog gathers most of his writings (Grupo de Pesquisa Diversidade Sexual, Cidadania e Religião 2017).
} 
attest to the ongoing questioning, openness to dialog, and changing and differing positions among Roman Catholics-which, in turn, gave rise to pressuring demands for revision and critical analysis of Catholic assumptions on sexual and gender diversity. Moreover, a significant number of Roman Catholics could not help but to acknowledge the violence and injustice arising from religious condemnation of non-conforming sexual and gender experiences. Compelled by a rapidly changing sociocultural landscape to reevaluate their own religious convictions, Catholic theologians, clergy, and lay people alike reached out for input not only from scientific experts in various fields of knowledge, but also from the LGBTQI+ community itself.

The examined publications also show that contact with the concrete lives of noncis-heterosexual people led to growing demands for a pastoral take on the issue of sexual and gender diversity. On the other hand, the repeated mentions of difficulties and fear reveal the threat of censorship and sanctions hanging over those who dared to approach the subject. The fact that clergy in certain religious orders might be less vulnerable to such risks would help us understand the crucial role played by Jesuit-, Redemptorist-, and Franciscan-owned publishing houses. Not coincidentally, those are the same orders most of the clergy accompanying the LGBTQI+ Catholic groups in Brazil come from, as we are about to see.

It was in such context that a handful of people in Rio de Janeiro would initiate a journey to shape their own take on reconciling sexual and gender diversity with their Roman Catholic faith and belonging. The movement they started in the mid-2000s would give rise to and consolidate new theological and ecclesial subjects in Brazilian Catholicism.

\section{Overview of LGBTQI+ Roman Catholic collectives in Brazil}

In 2005, a garish pink-covered book featuring a black-and-white butterfly in a bookstore window caught the attention of a young Roman Catholic priest, then pursuing his master's degree in theology. It was the compilation by Jung and Coray (2015). As he recalls it, reading the "pink book" was crucial for him to recognize and accept his own homosexuality, which would eventually lead him to the decision to leave the priestly ministry. Only then could he say, "I am gay," instead of "I have a problem." From then on, the desire emerged to "help other people who, being Catholic, realized that they were gay, or vice versa." 18

That young priest and a few others, accompanied by a Jesuit priest, began to meet to pray, study, and discuss how to reconcile what they called their "dual identity"being simultaneously Roman Catholic and LGBTQI+. Their original intention was to create a website providing theological resources for reconciling sexual and gender diversity with the Christian faith, especially in Roman Catholicism. However, once the www.diversidadecatolica.com.br website finally came out, on July 14, 2007, there arose an ongoing demand for face-to-face meetings. Meetings in Rio de Janeiro have been held, since then, mostly on a monthly basis. At first, about ten

18 Personal communication 
people, or even less, gathered; from the beginning of Francis' pontificate, though, the average number has leaped to between twenty and thirty people, occasionally more. Diversidade Católica ("Catholic Diversity") ${ }^{19}$ would become the first organized group of LGBTQI+ Roman Catholics in Brazil. ${ }^{20}$ That was the starting point of the LGBTQI+ Christian movement in the country.

In 2010, James Alison, an openly gay English priest who then lived in São Paulo, took the initiative of creating the second Brazilian group for pastoral accompaniment of LGBTQI+ Catholics. That same year, the Brazilian version of his book Faith beyond Resentment: Fragments Catholic and Gay came out (Alison 2010). It was the first Brazilian publication to offer theological reflections on sexual and gender diversity in a Roman Catholic perspective, based on the experience of an LGBTQI+ author. ${ }^{21}$ Besides Rio de Janeiro and São Paulo, from 2010 to early 2014 similar initiatives emerged in other cities across the country, such as Belo Horizonte and Brasília, followed by Ribeirão Preto (São Paulo), Curitiba, and Recife. In the case of Brasília, two former members of Diversidade Católica Rio de Janeiro happened to move there, where they counted on the support of Jesuits to found their collective. Digital social networks were of crucial importance both in disseminating the existence and ideas of those communities and in facilitating communication among people and groups across the country in search of support, welcoming, guidance, inspiration, and safe environments for exchanging experiences.

In June 2012, Diversidade Católica Rio de Janeiro held its first one-afternoon public seminar, widely publicized on its digital platforms, entitled "The love of Christ has united us: Christian gays in the Catholic Church." The program included a presentation of the group's history, a roundtable (which included James Alison) to debate the Roman Catholic doctrine on sexual and gender diversity, and a series of personal testimonies. In July 2013, during Pope Francis' visit to Rio de Janeiro for World Youth Day (WYD), the group held another public meeting. Entitled "The young homosexual in the Church: First meeting for exchanging experiences," it was also attended by six pilgrims representing Equally Blessed, a coalition of US LGBTQI+ Catholic groups. In October, a "Second meeting for exchanging experiences" was held, now on "Gays and their families."

In 2014, on the eve of the 18th LGBT Pride Parade in São Paulo, following an anonymous complaint, representatives of the local LGBTQI+ Catholic collective, then called "Pastoral da Diversidade" ("Diversity Pastoral Council"), were summoned to a meeting with an auxiliary bishop of the Archdiocese. He ordered that the group changed its name, since in Brazil that use of the word "pastoral" refers to organizations within the official diocesan structure. The collective then adopted the name "Grupo de Ação Pastoral da Diversidade (GAPD, which would roughly

\footnotetext{
${ }^{19}$ Later, other groups would adopt the same name, differentiating themselves by adding to it their city of origin. Some, seeking to express an ecumenical stance, have chosen the name "Diversidade Cristã" ("Christian Diversity").

${ }^{20}$ Serra (2019, pp. 177-186) tells in richer detail Diversidade Católica Rio de Janeiro's story.

${ }^{21}$ Alison would leave Brazil for Spain a few years later. He would also play a central role in GNRC's foundation, in 2015, and up until this writing is an active member of GNRC's Theological Committee.
} 
translate as "Group for Pastoral Action towards Diversity"). In return, they negotiated a note by the Archdiocese's Justice and Peace Committee, asking "people of good will, especially all Christians, to reflect on this profoundly unjust reality of the LGBT people and to actively commit themselves to its overcoming, guided by the supreme principle of human dignity" (in Serra 2019, pp. 25-26).

A little over a month later, on July 26, Diversidade Católica Rio de Janeiro hosted the First National Assembly of LGBT Catholics. On that occasion, delegates from five groups (Rio de Janeiro, São Paulo, Brasília, Curitiba, and Ribeirão Preto) founded the Rede Nacional de Grupos Católicos LGBT (RNGC, National Network of Catholic LGBT Groups). They released a manifesto, which began by stating: "We, LGBT Catholic Christians [...] are daughters and sons of God and of the Church" (RNGC 2014). By 2015, other communities would be created in Iguatu (Ceará), Fortaleza (after a former member of the Rio de Janeiro group moved there), Mossoró (Rio Grande do Norte), and Maringá (Paraná); in 2016, supported by the Brasília community, another group would be founded in Teresina.

In 2015, Diversidade Católica Rio de Janeiro organized a roundtable to promote the release of the book Catholic Homosexuals: Getting Out of the Impasse, published in Brazil by Edições Loyola (Maldonado 2015). Author Claude Besson is a former Cistercian monk and co-founder of the French association Réflexion et Partage, who is dedicated to "improving the welcoming of homosexual people in the Catholic Church" (Besson 2015). Weeks later, Diversidade Católica Rio de Janeiro and GAPD would both send delegates to the first GNRC assembly, in Rome.

Contrasting with the situation faced by GAPD in 2014, between 2016 and 2017, official "Sexual Diversity Pastoral Councils" would be created in both Nova Iguaçu (Rio de Janeiro) and Belo Horizonte, with the approval and support of their respective (arch)bishops. The one in Nova Iguaçu was personally announced by then bishop (now retired) Luciano Bergamim, who even granted an interview and posed for a photo for a newspaper towards the end of 2017 (Ricardo 2017). In Belo Horizonte, there would be two Sexual Diversity Pastoral Councils, one created in 2016 and the other in 2017. In the Archdiocese of Curitiba, there has been a "Catholic Group for Pastoral Care towards LGBT People" since 2015.

RNGC remained largely inactive until 2017, when some of the people who had taken part of the First National Assembly back in 2014 decided to organize a new meeting. In June 2018, GAPD hosted the Second National Assembly of LGBTI+ Catholics in São Paulo, gathering around sixty participants, from fifteen different collectives. On that Second National Assembly, a constitution and a board were created to enable RNGC to play a more effective role in supporting and integrating member communities, producing and participating in activities and establishing partnerships with other organizations.

Shortly after the Second Assembly, two new groups were created, now in Campinas (São Paulo) and Itaquera-the latter was the second group in the city of São Paulo. By 2021, RNGC had been joined by new communities in Brasília, Fortaleza, and São Luiz, as well as in Guarulhos (São Paulo), Rio de Janeiro, and São João de Meriti (Rio de Janeiro). In September 2021, the network comprised 23 lay communities spread throughout the country, except for the Northern region.

The Brazilian LGBTQI+ Roman Catholic groups are heterogeneous. Some have been created on the initiative of either clergy or lay people interested in carrying out 
pastoral work aimed at LGBTQI+ people. One of them has been founded in a parish in Rio de Janeiro on the initiative of parishioners who were parents of LGBTQI+ people. In most cases, however, lay Catholics who identify as LGBTQI+ have created such communities out of need. Many of them arise from contacts, via digital social networks, with already existing collectives, which support and aid newer groups struggling to consolidate. Most have succeeded in moving from virtual contacts in Facebook or WhatsApp groups to regular face-to-face meetings. Some have eventually dissolved, while others have faced greater difficulties in holding regular in-person meetings.

Most of the groups seek the support of priests for spiritual and pastoral accompaniment and mass celebration. Many of them organize or participate in open conferences or meetings on subjects related to sexual and gender diversity, either on a theological approach or not. Diversidade Cristã Brasília is officially responsible for the liturgy of a monthly mass in the Jesuit cultural center where they congregate. In São Paulo, GAPD meets in a place belonging to Franciscans; the LGBT Pastoral Movement Marielle Franco (MOPA) was born, welcomed, and integrated into the community of the Our Lady of Mount Carmel parish in Itaquera, counting on the support and encouragement of the parish priest and a Salesian Sister.

In fact, most of the groups are accompanied by clergy, which provide them with places to congregate, celebrating mass and taking communion. Mostly priests, although there are also a couple of nuns, they usually belong to religious orders (especially Jesuits and, in Northeastern Brazil, Redemptorists), which tend to be more independent and suffer less direct pressure from local bishops. There are peculiar experiences, though—such as that of a community called Filho de Davi ("Son of David"), from Iguatu, a small city in Southern Ceará, in the Brazilian Northeast. They have held their monthly meetings, for most of its history, in squares and public places; only later have they started meeting in a local parish, accompanied by a priest. There are also reports of meetings in the homes of group members; this is how Filho de Davi celebrated a triduum in honor of St. Mary Magdalene, their patroness saint, in 2019.

A significant number of members of the Brazilian LGBTQI+ Catholic collectives maintain some connection with their original parishes, or even remain in charge of activities therein, either as pastoral agents, youth group leaders, catechists, acolytes, lay Eucharistic ministers, or engaged in the preparation for Confirmation, or in liturgy, music, or reading. They are mostly middle-class, white cisgender gay men with access to superior education — which makes intersectionality a crucial issue for debate in RNGC.

However, despite their distinctive profiles and stories, gifts, and charisms, which correspond to a wide diversity of experiences, the Brazilian LGBTQI+ Roman Catholic communities share some significant features. In the words of the RNGC Board:

These are lay collectives that organize themselves out of the need to create safe spaces for those who seek to reconcile their Roman Catholic religious belonging with their LGBTQI+ identities. They organize to create safe spaces where to be respectfully welcomed, share experiences and live their Christian faith in community. These are spaces for meeting and exchange, for reflection and 
listening, for deepening our faith and spirituality together. (Serra et al. 2020, p. 50)

Amid the mushrooming of online activities during the COVID-19 pandemic quarantine in 2020, RNGC held their first Instagram live, on March 24. There followed an online celebration of Lent, an online Easter triduum, and the launching of their website. In May, there were three Instagram lives and a celebration themed on women and their place in the Church, a series of seven videos in preparation for Pentecost, and a Pentecost online celebration. In June, LGBTQI+ Pride Month, they carried out an online campaign of testimonies by members of their communities, using the hashtag "Testimonies of Diversity," followed by an online Pride celebration.

In July 2020, lesbian, bisexual and transgender women, non-binary people, and allied women of the RNGC member groups launched a special community, named Núcleo Madalenas (“The Magdalenes' Group”). They aimed at "empowering and increasing the representation" of women in RNGC groups, as well as at:

Sharing experiences and promoting new conversations on religion, gender and diversity, in order to make our experiences as people of faith visible and valid. Committed to Jesus Christ's Gospel, we search for self-knowledge and invest in female leadership in our Catholic LGBTQI+ collectives, as well as in building real diversity, which is an attribute of the loving divine creativity and a central value in our network. (Madalenas 2021)

That same month, RNGC celebrated its sixth anniversary. On that occasion, an e-book gathering the 21 testimonies collected in the "Testimonies of Diversity" campaign was released. In August, there was an online celebration of lesbian visibility. Meanwhile, online celebrations and activities held by RNGC member communities also proliferated, as well as exchanges among them. Due to the COVID pandemic, RNGC put off their Third National Assembly, originally scheduled for June 2020, to November 2021.

The Brazilian LGBTQI+ Catholic communities have usually taken the initiative to inform in writing both the local (arch)diocese and the Brazilian Episcopal Conference whenever they gather for a regional or national meeting. Their stated intention is to let the bishops know of their meetings in advance, not to ask for permission to gather. In a couple of other occasions, RNGC contacted the National Episcopal Conference to critically comment on specific situations concerning sexual and gender diversity issues and the Catholic Church in Brazil. Since there has never been a response of any kind, it appears that the Brazilian bishops would rather not acknowledge the existence of an organized movement of LGBTQI+ Roman Catholics. In fact, under the current circumstances, strained as Latin America is by the radicalization of the anti-gender crusade, it seems unlikely that Brazilian bishops will be willing to engage in the kind of pastoral attention towards sexual and gender diversity advocated by Bergoglio-not at least, in official, institutional terms.

One case in point was the creation of both "Sexual Diversity Pastoral Councils" in Belo Horizonte. Significantly, a major newspaper has even described one of them as being "the result of the pope's new posture and the Church's review of family arrangements" (Cipriani 2017). Towards the end of 2018, however, a video on a 
small YouTube channel lashed out at the local archbishop for supposedly fostering "gender ideology" in the archdiocese. Cornered, the archbishop denied having given any support or even been aware of the existence of the two groups, ${ }^{22}$ which then took on other names to carry on with their activities, even without official support. That was a remarkable example of the tensions and paradoxes currently observed in Roman Catholic ecclesial environments, where distrust arising from the "witch hunt" atmosphere and fear of denunciation and persecution seem to have offset, at least partially, the so-called Francis effect.

On March 15, 2021, news that the CDF had issued a statement denying Roman Catholic clergy the possibility of blessing same-sex unions-under the claim that the Church could not "bless sin" (Ladaria 2021) - reverberated across the world. That same afternoon, RNGC issued a protest note on the matter (RNGC 2021a), whose English translation was then published in GNRC digital media and quoted the next day by London-based weekly Catholic review The Tablet. The quoted excerpt read:

We are outraged, but we are not surprised, because in this document we see that face of the Church that Christ himself criticized so harshly in the doctors of the law of His time. We see there that face of the Church that appropriates the power to interpret the Word of God not to propagate Life and make it flow in abundance, but to close doors and refuse to go to its People. By losing sight of the message of service, unconditional love and acceptance of the Gospel, the law becomes dead letter. This is the face of part of the Church, which falls, once again, into the empty legalism so often denounced by Christ. (in Roberts and Pongratz-Lippitt 2021)

Indeed, in the beginning of 2020, RNGC had joined GNRC as a member group, like Diversidade Católica Rio de Janeiro and GAPD. In May 2021, in the wake of the controversy around the CDF same-sex union blessings ban, they gathered virtually with other Latin American LGBTQI+ Catholic communities in an online Pentecost celebration in which participants blessed each other and celebrated the fact that they are Church. ${ }^{23}$

\section{Diversity as a gift: The Brazilian LGBTQI+ Catholic groups' theology}

Rather than discussing sexual and gender diversity in Roman Catholicism in the third person, the Brazilian communities that avowedly organize around identities that are simultaneously "Roman Catholic" and "LGBTQI+" take the floor publicly to attest to their presence in the Church. Once they acknowledge that they

\footnotetext{
${ }^{22}$ In May 2109, the archbishop of Belo Horizonte was elected president of the Brazilian Episcopal Conference. In the wake of his election, a major national newspaper interviewed him. On that occasion, he was asked about accusations of being "a communist, supporting the so-called gender ideology and the gay lobby," supposedly due to the creation of "a Sexual Diversity Pastoral Council [...] to welcome gays and lesbians in 2017" in Belo Horizonte. Asked if he had authorized it, he again alleged, "It was an initiative by two priests, without my knowledge [...] That is why I said clearly that there is no Sexual Diversity Pastoral Council in the Archdiocese" (Tavares 2019).

${ }^{23}$ Available at https://youtu.be/PYJvAEUcR0k. Accessed 15 Jun 2021
} 
are already present within the Church, they let go of an apologetic attitude and cease asking for permission to enter or remain in a Church where they already are. Thus, they position themselves as legitimate ecclesial and theological subjects. For instance, in June 2018, RNGC issued their Second National Assembly of LGBTQI+ Catholics' manifesto, which read:

We are the holy People of God, inalienable members of the Roman Catholic Church, and [...] we join the community of sisters and brothers baptized in Christ, contributing with our gifts, in all their diversity, to the Kingdombuilding journey. [...] For the sake of the Gospel, we are inspired by the prophetic task of proclaiming Hope, resisting oppression and denouncing injustice, and we commit ourselves to building a truly just and fraternal society for all people, without any distinctions. [...] We stay in communion with our sisters and brothers in Christ and we call upon the Church, communities of faith and the society as a whole to walk with us, making a preferential option for the excluded. [...]. (in Diversidade Católica 2018)

The Testimonies of Diversity e-book RNGC released in July 2020 is subtitled "Stories of faith, love and communion." Its afterword, signed by the RNGC Board, describes RNGC's lay collectives as safe spaces for the Catholic LGBTQI+ community. The authors explain that safe spaces are necessary "because the notion of an alleged incompatibility between sexual and gender diversity and religious belonging (especially belonging to Christianity in general, and to Roman Catholicism in particular) still prevails in the Church and in the world" (in Serra et al. 2020 , p. 50). The book's stories, they say, certainly bear witness to the violence stemming from such assumption; however, they also move beyond that.

These are stories of faith, because it is thanks to our faith that we carry on. Faith in Christ and in the Church. Faith in the Good News of Unconditional Love, of the Incomprehensible Love with which each and every one of us is loved. [...] Faith in the fresh and burning breath of the Holy Spirit of God that moves us, nourishes us and encourages us to remain in our Church, and to walk with our Church as the Body of Christ.

These are stories of love. They reveal our luminous friendship with Jesus, in all its complicity and trust. Because we walk with Him, [...] we are called, prophetically, to denounce violence and injustice and to announce the Kingdom. [...] Because our hearts are united with His, we see Him in our sisters and brothers, and the vital impetus to be Church and to work to produce abundant fruit as a community takes root in our hearts.

Therefore, these are stories of communion. Because, through faith and love, we are called to be the Body of Christ and work with Him to build the Kingdom [...]. Through faith and love, we create spaces where to plant seeds of life that nourish and enrich us. From there we go out to sow and generate good fruit, thus helping build a world where to find more justice and equality, a world where there is space for each person to flourish in diversity. (in Serra et al. 2020, pp. 50-51) 
In their pastoral, theological, and ecclesiological approach, the Brazilian LGBTQI+ Roman Catholic groups advocate a pastoral approach that is truly welcoming and respectful of each unique living experience of God. In fact, their experience translates into a theological praxis in which pastoral care, experience sharing, and testimonies figure as central features-whether in private meetings, public activities, or publications. In the words of the RNGC Board, "it is only in our living human experience, incarnated in our lives and in the lives of our communities of faith, that we who follow Jesus, the Incarnate Word of God, find Him, in the Temple of our bodies" (in Serra et al. 2020, p. 50).

Fostering a welcoming, respectful attitude towards each particular human reality, rooted in living, incarnated human experiences, leads to envisioning the inherent holiness of diversity itself, as the fruit of the "Infinite Creativity through which all Creation was begotten and brought to light, making the diversity of life a divine attribute" (in Serra et al. 2020, p. 50). Thus, diversity is to be celebrated as a gift. "Considering the plurality of God himself, revealed in the Holy Trinity and manifested in the multiple beauty of Creation, we strive for the recognition and full celebration of the diversity of expressions, identities, genders, sexualities, races, ethnicities, cultures and creeds" (in Diversidade Católica 2018).

In May 2021, RNGC offered a seven-session course entitled "Plural Theologies," consisting of modules on feminist, queer, and black theologies. The course's goals were described as follows:

First, to call into question the historical centrality of white, cisgender, male, heterosexual bodies in the production of the hegemonic Christian theology as we know it - a supposedly universal theology, although it is actually based on those specific experiences and worldviews, almost always aiming at maintaining an unequal world order [...]. Second, to present [...] other Christian theologies (plural form), particularly those produced [...] by women, blacks and LGBTQIA+ people, who have long been creating disruptive forms of resistance against such hegemony, denouncing injustices promoted by fundamentalist theologies, and prophesying other visions of God, the Bible, theology, and the Church. (RNGC 2021b)

When taking the floor to speak for themselves, the Brazilian LGBTQI+ Catholic collectives engage in simultaneous conversations with doctrinal discourses, activism's identity discourses, and the discourses of "experts" in human and social sciences. Appropriating those as well as their own voices allows them to overcome the ecclesiological conception that bestows the authority on the Ultimate Truth about God and human experience upon the Catholic magisterium. As a case in point, towards the end of 2013, GAPD, then still called "Pastoral da Diversidade," responded to the "preparatory document" of the 2014 Ordinary Assembly of the Synod of Bishops. Before answering the document's questions, they made the following general considerations:

[...] Lay people are more and more easily realizing that there is no objective disorder intrinsic to someone being LGBT. However, the clergy, even knowing that many belong to our tribe, cannot deal with this matter in an honest man- 
ner. [...] Existing pastoral efforts, based on which we wrote this letter, survive in hiding, without a sincere, open and fraternal welcome, in ecclesial spaces not recognized as such. We ask, therefore, not as a mere academic matter, but as an urgent exercise of pastoral responsibility, that you seek a way to publicly and honestly join us in elucidating whatever actually exists in this field - with no fear of the truth, otherwise no Catholic Pastoral Care is possible. (GAPD 2013)

Having critically acknowledged the magisterium's limitations, the Brazilian LGBTQI+ Catholic groups strive for greater moral autonomy and assert their selfknowledge and their own authority to speak for themselves. "Because we have Jesus in our lives, as our intimate and personal friend, we learn from Him to see ourselves with His eyes, and so we learn again and again the meaning of loving ourselves as He loves us" (in Serra et al. 2020, pp. 50-51). By doing so, they subvert the authority of the alleged holders of Sacred Truth; that, in turn, allows them to question the legitimacy of a Church capable of marginalizing, excluding, and perpetrating violence. A case in point is the manifesto released on the First National Assembly of LGBT Catholics, in 2014, which quotes Bergoglio to advise: "The Church must always be the Father's open house, where there is a place for all who face hardships in their lives. The Church is not a customs office for the sacraments. The confessional should not be a torture room, but a place where to finde mercy, a place where the Lord encourages us to do the best we can. The Eucharist is not a prize for the perfect, but a generous remedy and food for those in need" (RNGC 2014).

By appropriating that kind of authority, as well as the responsibility to utter the truth about themselves, those LGBTQI+ Catholic actors, both individually and collectively, become visible and vocal subjects within the Church. That results in two simultaneous outings. On the one hand, by coming out of the closet and making themselves visible in the Church, they prove the notion of a homogeneously binary cis-heterosexual Church wrong. The Church itself is outed as a much diverse terrain, in which a wide range of unique incarnated human experiences coexists. On the other hand, once Catholics come out of the closet as LGBTQI+, they equally out the LGBTQI+ community itself regarding the diversity of their members' religious affiliations and experiences of faith and of the sacred. By doing so, LGBTQI+ Catholics demonstrate how pervious the boundaries of what it means to be "Catholic" (and/or "Christian"), as well as of what it means to be "LGBTQI+," are. Ultimately, they pluralize both identities, thus expanding the limits of a world which assumes them to be irreconcilable.

Acknowledgements The author wishes to thank Sergio Carrara and Luís Corrêa Lima for their invaluable collaboration to the research leading to this paper, the reviewers for precious comments on the manuscript, the editors for their patience, and Brazil's Conselho Nacional de Desenvolvimento Científico e Tecnológico (CNPq) and Coordenação de Aperfeiçoamento de Pessoal de Nível Superior (CAPES) for research funding.

Author contribution Not applicable. 
Funding The research leading to these results has received funding from Brazil's Conselho Nacional de Desenvolvimento Científico e Tecnológico (CNPq) and Coordenação de Aperfeiçoamento de Pessoal de Nível Superior (CAPES).

Data availability All data and materials support published claims and comply with field standards.

Code availability Not applicable.

\section{Declarations}

Ethics approval Not applicable.

\section{Competing interests None.}

Financial interests The author declares she has no financial interests.

Non-financial interests The author has been a member of Diversidade Católica Rio de Janeiro since 2008, for which she receives no compensation. She has also served on the boards of both the Brazilian National Network of LGBT Catholic Groups (since 2018) and the Global Network of Rainbow Catholics (since 2020), receiving no compensation for performing such functions.

\section{References}

Alison J (2010) Fé Além do Ressentimento: Fragmentos Católicos em Voz Gay. É Realizações, São Paulo Althaus-Reid M (1994) When god is a rich white woman who does not walk: the hermeneutical circle of Mariology and the construction of femininity in Latin America. Theol Sexual 1(1). https://doi.org/ $10.1177 / 135583589400100105$

Althaus-Reid M (1997) Sexual strategies in practical theology: indecent theology and the plotting of desire with some degree of success. Theol Sexual 4(7). https://doi.org/10.1177/135583589700400 704

Althaus-Reid M (2000) Indecent theology: theological perversions in sex, gender and politics. Routledge, Londres/New York

Asad T (2011) Thinking about religion, belief, and politics. In: Orsi R (ed) The Cambridge companion to religious studies. Cambridge University Press, Cambridge, pp 36-57

Bárcenas K (2011) De los homosexuales también es el reino de los cielos. Las iglesias y comunidades cristianas para la diversidad sexual y de género en México. In: Revista del Centro de Investigación. Universidad La Salle, vol. 9, núm. 36, pp 45-58

Bárcenas K (2018) Pánico moral y de género en México y Brasil: rituales jurídicos y sociales de la política evangélica para deshabilitar los principios de un estado laico. Religião e Sociedade, Rio de Janeiro 38(2):85-118. https://doi.org/10.1590/0100-85872018v38n2cap03

Becker H (1997 [1963] Outsiders: studies in the sociology of deviance. Free Press, New York

Besson C (2015) Homossexuais católicos: como sair do impasse. Loyola, São Paulo

Brown W (2006) American nightmare: neoliberalism, neoconservatism, and de-democratization. Political Theory 34(6):690-714. https://doi.org/10.1177/0090591706293016

Butler J (2004) Precarious life: the powers of mourning and violence. Verso, London, New York

Butler J (2007 [1990]) Gender trouble: feminism and the subversion of identity. Routledge, New York

Catechism of the Catholic Church (1993). Chastity and homosexuality. In: Catechism of the Catholic Church. Libreria Editrice Vaticana, Vatican City. Available at https://www.vatican.va/archive/ ENG0015/_P85.HTM. Accessed 15 Jun 2021

CDF (1979) Letter to Archbishop John R. Quinn, president of the National Conference of Catholic Bishops in the U.S.A. Vatican City. Available at http://www.vatican.va/roman_curia/congregations/ cfaith/documents/rc_con_cfaith_doc_19790713_mons-quinn_en.html. Accessed 30 May 2021 
CDF (2001) Notification regarding certain writings of Fr. Marciano Vidal, C.Ss.R.. Vatican City. Available at https://www.vatican.va/roman_curia/congregations/cfaith/documents/rc_con_cfaith_doc_ 20010515_vidal_en.html. Accessed 30 May 2021

Cipriani J (2017) Santuário São Judas Tadeu tem primeira Pastoral da Diversidade Sexual de BH. In: Estado de Minas. Available at https://www.em.com.br/app/noticia/gerais/2017/06/12/interna_gerai s, 875818/santuario-sao-judas-tadeu-tem-1-pastoral-da-diversidade-sexual-de-bh.shtml. Accessed 15 Jun 2021

Cohen S (2011 [1972]) Folk devils and moral panics: the creation of the mods and rockers. Routledge, London/New York

Conselho Federal de Psicologia e Conselhos Regionais de Psicologia (2019) Tentativas de Aniquilamento de Subjetividades LGBTIs. Conselho Federal de Psicologia, Brasília. Available at https://site.cfp. org.br/wp-content/uploads/2019/06/CFP_TentativasAniquilamento_WEB_FINAL.pdf

Corrêa S (2020) Anti-gender politics in Latin America: summaries of country case studies. Associação Brasileira Interdisciplinar de Aids (ABIA), Rio de Janeiro. Available at https://sxpolitics.org/GPAL/ uploads/E-book-Resumos-completo.pdf. Accessed 21 Sept 2021

DeBernardo F (2015) Reporting from Rome on Rainbow Catholics Assembly and synod on the Family. In: New Ways Ministry website. Available at https://www.newwaysministry.org/2015/10/02/repor ting-from-rome-on-rainbow-catholics-assembly-and-synod-on-the-family/. Accessed 20 Jun 2021

DignityUSA (n.d.) DignityUSA history. In: DignityUSA website. Available at https://www.dignityusa. org/history. Accessed 20 Aug 2021

Diversidade Católica (2018) A Rede Nacional de Grupos Católicos LGBT lança seu manifesto. In: Diversidade Católica website. Available at http://www.diversidadecatolica.com.br/2018/06/07/796/. Accessed 09 Jun 2021

Duarte L (2005) Ethos privado e justificação religiosa: negociações da reprodução na sociedade brasileira. In: Heilborn $\mathrm{M}$ et al (orgs) Sexualidade, Família e Ethos Religioso.: Garamond, Rio de Janeiro, pp 137-175

Encarnación O (2016) Out in the periphery: Latin America's gay rights revolution. Oxford University Press, New York

Fassin E (2011). A double-edged sword: sexual democracy, gender norms and racialized rhetoric. In: Butler J, Weed E (org.). The question of gender: Joan W. Scott's critical feminism. Indiana University Press, Bloomington. Available at https://muse.jhu.edu/chapter/382103

Frayser S, Whitby T (1995) Studies in human sexuality: a selected guide. Libraries Unlimited, Englewood

Freire, A (2019) Armários queimados: igreja afirmativa das diferenças e subversão da precariedade. 298 f. Tese (Doutorado em Ciências da Religião) - Programa de Pós-Graduação em Ciências da Religião, Pontifícia Universidade Católica de Minas Gerais (PUC Minas), Belo Horizonte

Gallagher R (1979) Understanding the homosexual. Furrow 30(9): 555-569. Available at www.jstor.org/ stable/27660799. Accessed 30 May 2021

Gallagher R (1990) Compreender o Homossexual. Santuário, Aparecida

GAPD (2013) Carta de Católicos LGBT para os Bispos - e petição para assinar. In: Diversidade Católica Blog. Available at http://diversidadecatolica.blogspot.com.br/2013/12/carta-de-alguns-grupos-decatolicos.html. Accessed 09 Jun 2017

Gibbs J, Goldbach J (2015) Religious conflict, sexual identity, and suicidal behaviors among LGBT young adults. Arch Suicide Res 19(4):472-488. https://doi.org/10.1080/13811118.2015.1004476

Girard F (2008) Negotiating sexual rights and sexual orientation at the UN. In: Parker R, Petchesky R, Sember R (eds) Sex politics: reports from the front lines. United Nations, Mexico City Available at https://www.sxpolitics.org/frontlines/book/pdf/capitulo9_united_nations.pdf

GNRC (2015) Dear sisters and brothers at the synod on the family. Facebook post. Available at https:// www.facebook.com/GlobalNetworkofRainbowCatholics/photos/a.1076649452375126.1073741829. 1069528526420552/1081451301894941/?type=3. Accessed 20 Jun 2021

Goffman E (1986 [1963]) Stigma: notes on the management of spoiled identity. Simon \& Schuster, New York

Green J (1999) Beyond carnival: male homosexuality in twentieth-century Brazil. The University of Chicago Press, Chicago/London

Grupo de Pesquisa Diversidade Sexual, Cidadania e Religião (2017) In: Grupo de Pesquisa Diversidade Sexual, Cidadania e Religião's blog. Available at http://www.diversidadesexual.com.br/. Accessed 29 May 2021

Haraway D (1988) Situated knowledges: the science question in feminism and the privilege of partial perspective. Fem Stud 14(3):575-599. https://doi.org/10.2307/3178066 
Helminiak D (1998) O que a Bíblia realmente diz sobre a homossexualidade. Summus/Edições GLS, São Paulo

Helminiak, D (2016) Story of this book. In: Visions of Daniel: Daniel A. Helminiak's website. Available at http://www.visionsofdaniel.net/book3WBRS.htm. Accessed 27 May 2021

Jones D, Vaggione J (2012) Los vínculos entre religión y política a la luz del debate sobre matrimonio para parejas del mismo sexo en Argentina. Civitas 12(3):522-537. https://doi.org/10.15448/19847289.2012.3.13050

Jung P, Coray J (2015 [2001]) Sexual diversity and Catholicism: toward the development of moral theology. Liturgical Press, Collegeville

Kosnik A et al (1977) Human sexuality: new directions in American Catholic thought. Paulist Press, New York

Kosnik A et al (1982) A sexualidade humana: novos rumos do pensamento católico americano. Vozes, Petrópolis

Ladaria L (2021) Responsum of the Congregation for the Doctrine of the Faith to a dubium regarding the blessing of the unions of persons of the same sex, 15.03.2021. Available at https://press.vatican.va/ content/salastampa/en/bollettino/pubblico/2021/03/15/210315b.html. Accessed 20 Mar 2021

Leers B (1988) Homossexuais e ética da libertação. Perspectiva Teológica 20(52): 293-316. Available at https://faje.edu.br/periodicos/index.php/perspectiva/article/view/1669/1997. Accessed 25 May 2021

Leers B (2002) Homossexuais e ética cristã. Convergência, pp. 565-576. Available at http://www.diver sidadesexual.com.br/wp-content/uploads/2013/04/Leers-Converg\%C3\%AAncia-out-2002.pdf. Accessed 01 May 2021

Leite V (2019) "Em defesa das crianças e da família": Refletindo sobre discursos acionados por atores religiosos "conservadores" em controvérsias públicas envolvendo gênero e sexualidade. Sexualidad, Salud y Sociedad 32. https://doi.org/10.1590/1984-6487.sess.2019.32.07.a

Libânio J (2009) A Igreja e os secularismos: Campo para o profetismo. In: IHU On-line, ed. 320, ano IX, pp 10-12. Available at http://www.ihuonline.unisinos.br/media/pdf/IHUOnlineEdicao320.pdf. Accessed 06 Jan 2021

Lima L (2005) A Igreja, o Papa e os Homossexuais. In: O Globo. Rio de Janeiro, p. 7. Available at http:// www.diversidadesexual.com.br/wp-content/uploads/2013/04/A-Igreja-o-papa-e-os-homossexuais. pdf. Accessed 06 Jan 2021

Lima L (2010) Homossexualidade e contra-hegemonia no catolicismo. In: Costa H et al. Retratos do Brasil Homossexual: fronteiras, subjetividades e desejos. EDUSP e Imprensa oficial do Estado de São Paulo, São Paulo, pp. 423-430. Available at http://www.diversidadesexual.com.br/wp-content/uploa ds/artigos-professor/Homossexualidade\%20e\%20Contra-hegemonia.pdf

Lima L (2021) Teologia e os LGBT+: Perspectiva Histórica e Desafios Contemporâneos. Vozes, Petrópolis

Machado M, Piccolo F (2010) Religiões e homossexualidades. FGV, Rio de Janeiro

Madalenas N (2021) Inspiradas por Ruah e com a bênção de Santa Maria Madalena.... In: Núcleo Madalenas Instagram profile. Available at https://www.instagram.com/p/CMKPv0ML7dJ/. Accessed 26 Jun 2021

Maldonado M (2015) Eu, o Outro e Todos Nós: Intermediações possíveis entre homossexuais católicos e os cânones da Igreja. In: Diversidade Católica Blog. Available at http://diversidadecatolica.blogspot. com.br/2015/08/eu-o-outro-e-todos-nos-intermediacoes.html. Accessed 05 Jun 2021

Mattos L (2002) Apresentação. In: Trasferetti J, Leers B (eds). Homossexuais e Ética Cristã, Átomo e Alínea, Campinas, pp 9-12

Moser A (2001) O enigma da esfinge: a sexualidade. Vozes, Petrópolis

Mott L (2006) Igreja e homossexualidade no Brasil: cronologia temática, 1547-2006. Comunicação apresentada no II Congresso Internacional sobre Epistemologia, Sexualidade e Violência. São Leopoldo (RS): Escola Superior de Teologia. Available at https://luizmottblog.wordpress.com/igreja-e-homos sexualidade-no-brasil-cronologia-tematica-1547-2006/. Accessed 07 Jun 2021

Musskopf A (2008) Via(da)gens teológicas: itinerários para uma teologia queer no Brasil. 2008. 524 f. Tese (Doutorado em Teologia) - Instituto Ecumênico de Pós-Graduação, Escola Superior de Teologia, São Leopoldo (RS). Available at http://dspace.est.edu.br:8080/jspui/handle/BR-S1FE/623. Accessed 03 Jun 2021

Musskopf A (2021) Fazemos a teologia que podemos: Igrejas inclusivas na América Latina nas décadas de 1980 e 1990. Editora Senso, Belo Horizonte 
National Catholic Reporter (1966) Vatican asks French to curb Fr. Oraison. National Catholic Reporter 2(39). Available at https://thecatholicnewsarchive.org/? $\mathrm{a}=\mathrm{d} \& \mathrm{~d}=\mathrm{ncr} 19660803-01.2 .4 \& \mathrm{e}=\% 2 \mathrm{D} \%$ 2D\%2D\%2D\%2D\%2D-en-20\%2D\%2D1\%2D\%2Dtxt-txIN-------. Accessed 23 May 2021

Oraison M (1977) A Questão Homossexual. Nova Fronteira, Rio de Janeiro

Peñas M, Sgró M (eds) (2009) Género y Religión: pluralismos y disidencias religiosas. Católicas por el Derecho a Decidir, Córdoba

Quentin Y (2015) In Memoriam: Émile Letertre. In: European Forum of LGBT Christian Groups website. Available at http://www.euroforumlgbtchristians.eu/index.php/en/european-forum/our-history/ in-memoriam/202-in-memoriam-emile-letertre.

Ricardo I (2017) Diocese de Nova Iguaçu cria Pastoral da Diversidade e divide opiniões. In: Extra. Available at https://extra.globo.com/noticias/rio/diocese-de-nova-iguacu-cria-pastoral-da-diversidadedivide-opinioes-22065613.html. Accessed 25 Feb 2021

RNGC (2014) Manifesto de grupos católicos LGBT do Brasil (2014). In: Diversidade Católica's website. Available at: http://www.diversidadecatolica.com.br/wp-content/uploads/2017/01/DC-Manif-Cat\% C3\%B3licos-LGBT.pdf. Accessed in: 25 May 2021

RNGC (2021a) Nota sobre declarações da Congregação para a Doutrina da Fé. In: RNGC website. Available at https://www.redecatolicoslgbt.com.br/noticia.php?id=87. Accessed 20 Mar 2021

RNGC (2021b) Teologias Plurais: curso introdutório online. Available at https://www.muropequeno.com/ event-details/teologiasplurais. Accessed 20 Jun 2021

Roberts J, Pongratz-Lippitt C (2021) German bishops 'not happy' with same-sex blessing rule. In: The Tablet website. Available at https://www.thetablet.co.uk/news/13952/german-bishops-not-happywith-same-sex-blessing-rule. Accessed 20 Mar 2021

Rubin G (2012 [1984]) Thinking sex: notes for a radical theory of the politics of sexuality. In: Deviations: a Gayle Rubin reader. Duke University Press, Durham. https://doi.org/10.1215/9780822394068-006

Serra C (2019) Viemos pra comungar: os grupos de católicos LGBT brasileiros e suas estratégias de permanência na Igreja. Metanoia, Rio de Janeiro

Serra C, Silva J, Araújo M (orgs) (2020) Testemunhos da Diversidade: Histórias de fé, amor e comunhão. Autorale, Rio de Janeiro. Available at https://drive.google.com/file/d/1brwAXLhawHjMG3yHRqe ivkm3Ct_FKIhB/view. Accessed 20 Jan 2021

Serrano J (2017) La tormenta perfecta: Ideología de género y articulación de públicos. Sexualidad, Salud y Sociedad, n 27:149-171. https://doi.org/10.1590/1984-6487.sess.2017.27.09.a

Shine R (2021) Pope Francis affirms need for lesbian/gay pastoral care, criticizes "gender ideology". In: New Ways Ministry website. Available at https://www.newwaysministry.org/2021/09/22/pope-franc is-affirms-need-for-lesbian-gay-pastoral-care-criticizes-gender-ideology/. Accessed 22 Sept 2021

Simões J, Facchini R (2009) Na trilha do arco-íris: Do Movimento Homossexual ao LGBT. Fundação Perseu Abramo, São Paulo

Snoek J (1967) Eles também são da nossa estirpe: considerações sobre a homofilia. In: Revista Vozes, ano 61, pp. 792-803. Available at http://www.diversidadesexual.com.br/wp-content/uploads/2013/ 04/Jaime-Snoek-art-1967.pdf. Accessed 29 May 2021

Tavares J (2019) Nem Igreja Católica nem governo é o dono da verdade, diz novo presidente da CNBB. In: Folha de São Paulo. Available at https://www1.folha.uol.com.br/poder/2019/05/nem-igreja-catol ica-nem-governo-e-dono-da-verdade-diz-novo-presidente-da-cnbb.shtml. Accessed 27 Jun 2021

The Furrow (n.d.) Welcome to The Furrow. In: The Furrow website. Available at http://thefurrow.ie/. Accessed 30 May 2021

Trasferetti J (1995) Sacerdote quer criar pastoral gay. In: Folha de São Paulo. Available at http://www1. folha.uol.com.br/fsp/1995/9/10/brasil/37.html. Accessed 26 May 2021

Trasferetti J (1998) Pastoral com homossexuais: retratos de uma experiência. Vozes, Petrópolis

Trasferetti J (2008) Modernizar o catolicismo com amor ao próximo e solidariedade. In: IHU Online, São Leopoldo (RS), ed 253, pp 12-13. Available at http://www.ihuonline.unisinos.br/edicao/253. Accessed 26 May 2021

Trasferetti J, Leers B (2002) Homossexuais e Ética Cristã. Átomo e Alínea, Campinas

Vaggione J (2005) Reactive politicization and religious dissidence: the political mutations of the religious. Soc Theory Pract 31(2):233-255 Available at https://www.pdenet.org/soctheorpract/content/ soctheorpract_2005_0031_0002_0233_0256

Vaggione J (ed) (2008) Diversidad Sexual y Religión. Católicas por el Derecho a Decidir, Córdoba

Vaggione J (ed) (2010) El activismo religioso conservador en Latinoamérica. Católicas por el Derecho a Decidir, Córdoba 
Vaggione J (2014) La politización de la sexualidad y los sentidos de lo religioso. In: Sociedad y Religión $n^{\circ}$ 42, Vol XXIV, pp 209-226. Available at https://www.redalyc.org/pdf/3872/387239045010.pdf

Vaggione J (2017) La Iglesia Católica frente a la política sexual: la configuración de una ciudadanía religiosa. Cadernos Pagu (50), 2017:e175002. https://doi.org/10.1590/18094449201700500002

Vaggione J (2020) The conservative uses of law: the Catholic mobilization against gender ideology. Social Compass 67(2):252-266. https://doi.org/10.1177/0037768620907561

Vaggione J, Machado M (2020) Religious patterns of neoconservatism in Latin America. Polit Gend 16(1):E2. https://doi.org/10.1017/S1743923X20000082

Vidal M (2008) Sexualidade e Condição Homossexual na Moral Cristã. Santuário, Aparecida

Vidal J (2012) 'Probe' Marciano Vidal. In: Nueva censura a un teólogo por temas de moral sexual. Atrio website. Available at https://www.atrio.org/2012/02/nueva-censura-a-un-teologo-por-temas-demoral-sexual/. Accessed 15 Jun 2021

Vidal M et al (1998 [1985]) Homossexualidade: ciência e consciência. Loyola, São Paulo

Pierucci A (1989) Representantes de Deus em Brasília: a bancada evangélica na Constituinte. In: ANPOCS. Ciências sociais hoje. Vértice/Revista dos Tribunais, São Paulo

Publisher's Note Springer Nature remains neutral with regard to jurisdictional claims in published maps and institutional affiliations. 